\title{
Between Isaac Hindom and Acub Zainal
}

\author{
Ismael Bauw
}

When Acub Zainal was running for governor, I was thrown out (reassigned). We were provoked. I was accused of rejecting Acub Zainal and backing Isaac Hindom. Acub Zainal was furious with me. Straight away I told Acub: 'I'm siding with Hindom because I'm related to him. But whether he wins, or you win, it's the same to me. I don't mind either that you follow Islam.' I started reciting a verse or two from the Qur'an. Then Acub Zainal said: 'Yes, yes, you're right!'

Acub Zainal was a good man. He developed Dok II well. Once I was knocked upside down by a pedicab in the street. He saw I was with my niece and her friend. We had just seen a film and were heading home. I had suggested we take two pedicabs, but they did not want to. Then we keeled over in front of Pak Acub Zainal's place. He saw us and came outside and said: 'Hey, what are you doing?' I answered: 'I have these two youngsters with me. I told them we should take two pedicabs, but they didn't want to.' Then he said: 'Never mind, get out of the pedicab and come inside for a chat'. Acub took very good care of the local people, too. But there was someone from Central Java in the governor's secretariat who messed things up. Acub Zainal appointed A.S. Onim as bupati of Merauke, then Jacob Pattipi. So Acub Zainal looked at whether or not a person could do the job. And he also did everything he could for regional development. Previously, the elementary schools in the villages only went up to the third grade. Then we changed them to go up to the sixth grade.

\section{ENTERING THE SCHOOL FOR ADMINISTRATORS}

At the end of the exams at the Jongens Vervolgschool, which were equivalent to elementary schools, the government admitted two or three 
local children from the elementary schools that had local students in each onderafdeling (sub division) to study at the Bestuursschool (School for Administrators) in Hollandia-Binnen (Abepura). At the time, four of us - I, Jacob Pattipi, Thomas Keskendik and Achmad Iribaram - were accepted into the Bestuursschool. The school was funded by the government. At the Bestuursschool, the first two years of education consisted of general studies from the Mulo (junior high school) curriculum and a few administration subjects. Then, in the third year, we were assigned to the sub-division and district-head offices to carry out administrative duties for a year. After the year-three practice, in year four we returned to the Bestuursschool, whose name had by then been changed to Opleidingsschool voor Inheemse Bestuursambtenaren (OSIBA, School for Indigenous Administrators), and studied there for two more years. So we were educated for five years in all. Anyone who could successfully complete this five-year education programme was promoted to the position of candidaat bestuurassistent (assistant administrator candidate) and placed in an administrative sub-division or district-head office to carry out government duties there.

After two years of general education I was assigned in Kaimana. I served for six months in Arguni Bay, where I performed duties in the area of taxation and governance, as well as supervising schools and doing judiciary tasks. We were educated to serve as judges and prosecutors. Each month we went out on a 20-day patrol of the villages and spent 10 days working at the office. I made use of those 20 days to visit the schools, which in those days were in very sorry condition. The education provided at the village schools at the time was only three years long, and led by a teacher who was a former evangelist, not a graduate of the Teacher Training College - known as Kweekschool in those days. There was a teacher who had come from Maluku as an evangelist, but because he taught so well, he was appointed as school headmaster and was in charge of the schools. That was in 1955-1956.

In 1956 I returned to OSIBA to study for another year. I saw that three years of elementary school was not enough. In my mind I aimed to add more years, although at the time I was not yet assigned to work independently, so I did not have the authority to make the improvement, in addition to the fact that I went off to follow studies in the Netherlands - an internship in the municipality of Rijswijk ZH. If you wanted to do something, you had to be independent and have full authority. At 
the time I was only seconded to the HPB. So I just carried out the tasks that the HPB assigned me. That was okay. And I remained on duty in the court. Then I supervised people working on the road to the interior in Biak. After that, I was supposed to be transferred to serve as district head in Bosnik, but that did not happen; then I was transferred in 1962 to serve as chairman of Streekraad Fakfak (Fakfak Regional Council) in Fakfak.

The man serving as HPB when I first came to Biak was Mr. Sollewijn Gelpke. He was the former HPB of Fakfak. He was really sympathetic to me, since he was close to my brother, Raja Ibrahim Bauw of Rumbati in Fakfak. After that came HPB Van Eek and, finally, HPB Assink. Then Assink was replaced by Mampioper and moved to replace Du Buy as HPB in Fakfak. And I doubled as the chairman of the Fakfak Regional Council. When I was the leader of Fakfak sub-division, I set out to upgrade the elementary schools from offering three years to four or five years of education, and I managed to make the change step by step. The first place where I did this was at an elementary school in Goras, at the tip of Fakfak. The second was in Rumbati, in my father's village. I was not raised there, but in Babo, although Rumbati was my father's original village. I upgraded the elementary school there to six years. Then I did the same in Arguni. There were two Argunis: Arguni Kokas (on the north side of the Onim peninsula) and Arguni Kaimana (in the south).

I got along with the government employees, among others, Mr. Brand, and in Biak, Mr. Minderhout. They guided me well. Ah, my Dutch was not that good. Since Mr. Minderhout was a Kweekschool graduate, he was able to improve my faulty language. He asked me: 'What books do you need?' I replied: 'I need the Adatrechtbundel van Nieuw-Guinea. After he returned to Holland, he sent the book to me. In Biak we used that book in composing the Ordonnatie Streekraad (Ordinances of the Regional Council) of Biak Noemfor. Unfortunately, the book got burned by the Indonesian government in Biak because they thought it was colonial. I knew the colonel who did it quite well. I said: 'Pak, this is a mistake!' Then he answered: 'Is that so!' I said: 'We can use that book to gain knowledge'.

While in Biak I once judged a serious case involving a problem concerning coconut trees. The coconut palms had been planted by Abdul Kadir. But the village head, Andreas Ronsumbre said that the coconuts were his. I invited them to have a meeting. I said: 'Let's follow the method 
used in Fakfak. In Fakfak there are nutmeg tree plantation. Person "A" says, that plantation belongs to him, and person "B" says it belongs to him. If that's how it is, we'll just divide up the harvesting seasons. In the first season, it is " $\mathrm{A}$ " who harvests, in the next season, "B" who harvests.'

But Andreas would not listen to me. He insisted that the coconuts belonged to him. I did manage to settle another dispute about coconuts between two brothers, Jakob and Eliezer Rumbiak. There was a coconut palm that Jakob Rumbiak had planted, but Eliezer said that it was he who owned it. I came between them when Eliezer raised his machete, threatening to cut Jakob with it. I admonished them and Eliezer heeded me. Then I brought the two of them together.

At last, Eliezer embraced Jakob, crying. I said: 'Now everything is still alright. We can always plant more coconuts, but if Jakob dies, one cannot bring him back to life!' In the end we gathered up all the young coconut palms and planted them on the north side of Bromsi in the Padaido islands.

\section{REPRIMANDING THE POLICE}

All of the subjects we had been taught at the School for Administrators got used on the job. Government, police, criminal and civil sciences - all of them got used. All of them were still valid at the time. This is what I found interesting. The Criminal Law I applied when I taught at Cendrawasih University (Uncen) in the 1990s was the same Criminal Law I had learned at OSIBA from the commissarissen van politie (commissioners of police), and from authors like Meis, Stroband, and others. Likewise, when I matched the police subjects I had learned against the situation that I saw here in Jayapura, I could see that in carrying out their daily work, the police were not performing their police jobs very well.

I once chided them, and their chief as well, that the job of the police is to maintain civic order and public security (handhaving van openbare rust en orde). So that is what I ordered students to memorize, what had to be memorized, or they would not pass. They also had to memorize the charges issued in a lawsuit, known as ten laste legging van een vonnis in Dutch. But the difficulty was that they had no desire to do it.

The other day I was thinking that in Indonesia, with its hundreds of millions of people, if we organized a Dutch language course, it would 
not be carried out. Perhaps in Java they might want to learn the language. Mr. Hans de Groot said: 'Yes, this is how we may develop Dutch culture in Indonesia. So if you all can assist with this that would be fine.' I said: 'Okay, I can help with this too, only, our knowledge of Dutch is probably not up to date, is it? So how can we go about developing it?' Stien Heipon, who was assisting me, said: 'Just try discussing it (with the government) so they will send you to the Netherlands.'

Stien Heipon assisted me as an instructor. She was a graduate of the Algemene Lagere School (ALS, public primary school) where Dutch was the intermediary language. It was she who taught Dutch language. She was certified to teach by the Ministry of Education. Then, a few years ago, an official from the Department of Home Affairs made a plan to send me to the Netherlands for two weeks to two months to study. But the plan got cancelled, because he transferred from his position in the Badan Pendidikan dan Latihan (Badan Diklat, Education and Training Agency) to another division.

\section{RELATIONS WITH DUTCH EMPLOYEES}

My relationships with the Dutch employees were fine. There were Minderhout and Brand. Of the two, the one I felt closer to was Minderhout. It was in Biak, and I was invited to his home and we travelled to the villages together. He spoke in Dutch and I translated into Indonesian. If I could not do it, I would get a young Ambonese who was born in Biak to translate the Dutch words into the Biak language for the community. The Ambonese youth knew the Biak language well.

Among the HPBs who served in Biak, my relationship with HPB Assink was also good. I once protested to him when we were trying a case in kampung Mamoribo in West Biak, in which a teacher had raped his student. HPB Assink picked the lawyer, Olaf de Rijke. In 1957 De Rijke had crashed in an airplane flying between Owi and Biak, and broken his leg. But he went home, got treatment, and healed. In 1959 we had a meeting in West Biak. De Rijke was defending the accused in the rape case. At the time, ${ }^{1}$ Sollewijn Gelpke was HPB in Biak. I said to Sollewijn

H.W. Assink was HPB in Biak in 1957 and again in 1961-1962. J.H.F. Sollewijn Gelpke was HPB in Biak from 1957-1960 (Schoorl 1996:617). 
Gelpke: 'Sir, we should not listen to De Rijke. I know that this teacher is actually guilty.'

First, he had committed rape with a minor, with his student. And he had intentionally sent his wife home and was living alone. He clearly had evil intentions. Further, he went to the forest and tried to bury the fetus. He had committed three offences. I knew that he was guilty. Then Sollewijn said: 'Alright. After De Rijke has gone home, we'll decide'. He said: 'It would be embarrassing not to follow his counsel, since he is the lawyer. Yes, but according to criminal law, he really is guilty, so we'll just punish him.' Then De Rijke went home. By that time, Sollewijn Gelpke had been replaced by Assink. Assink said: 'Take a look at his case file. We'll sentence him to three months only.' The teacher cried. I said: 'Mansar (Sir), there's no use crying, because if I were the judge, you'd receive a sentence of more than five years. So that's it, just accept it!'

The perpetrator was a native of Biak. Teachers having sexual relations with the children at their schools - that was a frequent enough occurrence across Irian. Finally, I said to him: 'That's it, Pak, a three-month sentence only. Later, once you get out of the correctional institution, we'll give you a letter of good conduct, so you can work again as a teacher.' He said: 'I miss my wife and children'. I replied: 'Okay, but it doesn't matter'. Then he entered the institution. The food in that facility was good. The day we inaugurated that institution was on Princess Irene's birthday. Ah, how we feasted during the inauguration. We invited everyone to eat sate, and I saw that the teacher was there too. My, he had grown fat. In 1961, the teacher, because of good conduct (goed zedelijk gedrag), was asked to return to being a teacher.

Mr. Minderhout was an educator. We had guests from Brazzaville, from Africa, and from PNG, and I was usually invited to communicate with them. One thing that amazed me was that Minderhout would come in, bringing drinks for us. Once he served someone from PNG, who said: 'Wow, this is great, you people live here together. We in PNG each have our own distinct places to live.' I said: 'Here we live together. When I was in the Netherlands, the woman of the house kindly served me coffee.' She did not distinguish black from white, everyone was the same, there was no discrimination.

At the time, Minderhout was still a bachelor and he was fine. He was the best educator. Afterwards, he was assigned to Jakarta (after the UNTEA administration, he worked for the Dutch Embassy in Jakarta), 
and he translated papers inherited from the Dutch. Minderhout had learned Indonesian from Mr. van der Sluys, the director of OSIBA. So I talked about him when I was in the Netherlands and met Mr. van der Sluys. He asked: 'Who did you work with back then in Biak? I said: 'With J.W. Minderhout. Together we composed the verordeningen (regulations) for the Regional Council of Biak Numfor.' He said: 'Oh, Minderhout, he was the best. Yes, I taught him Indonesian language.'

\section{TRANSFER TO FAKFAK}

From Biak I moved to Fakfak to serve as chairman of the Regional Council and I directly doubled as the HPB. Because of the way the government was organized at the time, the HPB doubled as the chairman of the Regional Council, along with doubling as the duty harbour master, harbour administrator and administrator of prisons. Thus, I actually had a great many duties. It was because of this doubling of positions that I once clashed with an Indonesian prosecutor.

In Fakfak there was an Inheemse Rechtspraak (Indigenous Court). What was favourable to us at that time were the provisions of the law. Thus - to speak frankly - we could circumvent the inadequacies of Indonesian law. ${ }^{2}$ There was a man from Serui who wanted to marry a woman from Tanimbar. The prosecutor concerned was defending the Tanimbar woman, while I was defending the Serui man. The prosecutor claimed that the girl was underage. This was despite the fact that she was already 15 years old. And according to civil law, one was allowed to marry at 15 . The date of birth on the girl's birth certificate had been changed from 1952 to 1953, although she was born in 1952 (the event took place in 1967). I told Adi Andoyo, SH. about it. Adi Andoyo had a Eurasian wife. He said: 'Yes, but the prosecutor is a Christian'. But I countered: 'Yes, but we are talking about justice'. I usually got along very well with him, but in this case I felt he was not being fair.

Compared to other areas, Islam was most prevalent in Fakfak, due to the connections between Fakfak and Maluku. The same was true of Raja Ampat. In Raja Ampat there was a story about a woman from Cirebon (Java), who came there in search of spices, then married a Biak man.

\footnotetext{
2 In 1967 indigenous law was apparently still practiced in Fakfak, despite the fact that the Indonesians
} had already established formal Indonesian law in Irian. 
The Biak man embraced Islam and the woman from Cirebon spread the religion of Islam on Salawati island, Raja Ampat. I told this story to Mr. van der Leeden.

I have a collection of his writings on Adminsitrative Law in Sarmi. I said: 'Sir, can I borrow your book?' He was giving a lecture at school on 'An anthropological review of the entry of Islam to New Guinea'. So, based on this, Siti Farok came from Cirebon. She married Kawer, a Biak man. And their children were named Arfan and Mayalibit. Their graves are in Salawati. So, later on I proposed that the capital of Raja Ampat be established on Salawati. The Indonesians said: 'Just establish it in Waigeo'. I said: 'Waigeo is very productive, but it is too far north. We would be leaving Missool behind. Missool produces a lot too, it has mines. But Salawati is close - it is easy to go north and south from there.'

In terms of kinship, the Waigeo people were in fact still related to the Seram people. So if you want to conduct research on the Biak language, you should also link it to the languages of Yarotu, Wamesa, Eastern Seram, and Onim. They share words in common. Is it possible that they exchanged vows with one another? Once, a chief from Kimuri came to Doom and from there he saw the island of Waigeo. Then he asked: 'Oh, what island is that? Is it Waigeo island? If so, when I return home, I will die!' In fact, he went home and he died! It was really a superstition, but after he returned, he died. Ah, it might have been because they had sworn oaths with each other that he was not allowed to look upon the island of Waigeo. Yes, it is a superstition, but it really happened!

I did not serve long as the chairman of the Streekraad (Regional Council), only from September 1962 to April 1963. After that the Council only continued to operate until 1966, then was abolished. Both the Streekraad and the Landschapsrechtbank (Regional Court) were abolished in 1966, although I argued with the public prosecutor that the Landschapsrechtbank was more appropriate for Papuans, because the law in the villages did not fit the criminal law in effect in Indonesia. The law it applied was more understandable to the people. The Kitab Undang-undang Hukum Pidana (KUHP, Penal Code) of Indonesia was originally composed in the Tidorese language. I read it in The Hague, but I could not understand it. Then the Tidorese was translated into Dutch. Then the Dutch was cast into the Ordonnantie (ordinance or statute) of 1938, which the Engelbregt book contained. Then it was translated into Indonesian. 


\section{MUHAMMADIYAH}

On 30 September 1962 the Dutch government proclaimed: 'De Nederlandse bestuursbevoegdheid over dit gebiedsdeel is vandaag ten einde' (The Dutch government authority of this part of the Dutch realm has ended today). I instructed the students at Uncen to memorize that (in Dutch). The statement was made by Mr. H. Veldkamp, the vice-governor. Veldkamp was the former resident of Biak, so I knew him well. The statement was published in the Nieuw-Guinea Koerier. Perhaps it is still archived in Dok II.

But many of the Dutch books have been lost. The books I once ordered are gone. Menufandu's books have disappeared. My own thesis is lost. My thesis at Uncen has also disappeared. The books went missing from the Dok II library after the Indonesians arrived. They did not understand Dutch, so I carefully gathered all the books together. There was a Manadonese named Dayo. He was a librarian, and he assembled and stored all the books properly. I sent three young people to study law in Yogya. They returned and put all the books in order. After that I was transferred. Willem Rumainum, who studied at Leiden University, wrote a book about agrarian law and published it in a very fine, thick book. They got rid of that book too, or else someone took it. I said in Dok II that people were getting rid of the books. The exceptions were people like Doyo and the young people I had sent to study in Yogya, who could take proper care of books.

On 30 September 1962 during the UNTEA period, came Mr. Summersville who had also worked in Indonesia. First he was the resident of Fakfak, then he was withdrawn from that position to serve as director of home affairs in Dok II, Hollandia. His replacement in Fakfak was Mr. Lekham. He was an Englishman who had once served in Malaysia and his Malay was still good. So we could talk with him, no problem. Finally, came Mr. Daniels. He was a Trinidadian. He could understand no Indonesian at all. So it was rather difficult to communicate with him. Summersville served for only three months. Then he was replaced by Lekham. Lekham was good. He went on patrol to the interior even though he was old. Poor man, he travelled as far as Womberi.

On 30 April 1963 Daniëls surrendered the job of resident to Susiladi. First, the position was transferred to the Indonesian representative to the UN who was on duty here, Bapak Hidayat, who was Sundanese. Then Hidayat transferred the position to Susiladi. Susiladi worked 
for two years, and then he was replaced by Sukanda. One year later, Sukanda was replaced by Satiaprawijaya, also Sundanese. Then after another year or more, Satiaprawijaya was replaced by Onim, a Papuan. Then, during the Onim period I moved to Jayapura, where I served as secretary to the Regional Council until 1973. As council secretary, I organized the existing documents and composed reports on the sessions. I also helped them out when it was thought I might have some influence. But when Acub Zainal was to become governor, I was thrown out. The Dutch-era Streekraad was eliminated. What remained was only the Dewan Perwakilan Daerah Tingkat Provinsi, or Provincial Council of Representatives.

The Dewan Perwakilan Rakyat Daerah Tingkat II (DPRD, Regional Council of People's Representatives at the sub-provincial level) was only established in 1967. We established it in a meeting in Biak. At that time, none of the political parties had been founded yet, so each group was represented by their respective representatives. The Muslim congregation was represented by the Muhammadiyah group, and their representative was Nicolas Tanggahma. He came from Fakfak and was a member of the New-Guinea Council. People said: 'Nicolas Tanggahma sides with Muhammadiyah because he comes from Fakfak'.

But it was because he saw that the group that did much of the work for the community here was Muhammadiyah. They established schools and polyclinics. When we inaugurated the polyclinic in Abe Pantai in 1966, Tanggahma also attended. The polyclinic served all the residents there. They originated from Biak, Buton, Ternate and Nafri. And we helped them all. Because the people of kampung Nafri got along well with the Muslim community residing around Jayapura. (The only mosque for all of Hollandia in the Dutch period was established in kampung Nafri). They said: 'Sir, let those people just take this land, because the work is for a good cause'. So a plot of land was donated for an orphanage, free of charge. In 1967 Bapak Raja Ibrahim Bauw of Rumbati in Fakfak inaugurated the orphanage in Abe Pantai, which still exists today. At the orphanage we took care of children and schooled them. There were children there who graduated from school and became police officers, including some children from Wamena.

In the 1960s, at the time of Acub Zainal, there were already many Indonesians. But also still a lot of Ambonese. They were former members of the indigenous civil service who kept serving here until they retired. 
For example, Mr. Sohilait, and Mr. Patiapon, who has since died. The ways they used language were different. Recently I was thinking about the Indonesian language that was used in the Adatrechtbundel. The author, who was the Salawati district head at that time, was the father of Lukas Dailom. It made me happy to read the book because the Indonesian he used there was different. If we compare it to the way Indonesian is spoken today, it is different. He used the Indonesian that was then current in Eastern Indonesia, especially in Maluku, Ternate, and Manado.

I once altered the Indonesian used by Mr. Gosal in a book of his essays. Mr. Gosal came from Manado, and was my former teacher. $\mathrm{He}$ was also a teacher to Papuan leaders such as Thoontje Meseth, Markus Kaisiepo and Willem Inuri. Basically, he was a teacher to some important people in Irian. But I changed his writings. He wrote a book, and I changed the language he used in it. I told him: 'Bapak, forgive me, I am adjusting it to fit the culture of today.' It was better for me to admonish him then for the Javanese to do so, which would embarrass us. Pak Sorontou was upset with me. He said: 'Pak Gosal is a teacher to the Irianese'. But I had approached Mr. Gosal so his book could be changed. Because I had been one of his students, he was willing to accept the changes I proposed. I last visited him in 1996 in Manado. He had two children, one in the Netherlands and one in Curaçao.

\section{PERSUADING MBAK TUTUT}

In accordance with the New York Agreement, the Indonesian government began to come in on 1 May 1963. But before that, the Netherlands had handed the leadership of the government in the regions over to the Papuans. At that time, Papuans were not as advanced as they are today. Some were advanced, but others were not. Later, when Acub Zainal became governor, he saw locals who could work and gave them the opportunity to do so, such as A.S. Onim, who became the first bupati of Merauke. First Onim, then Patipi.

When the Dutch were here we were already dealing with Dutch companies. Since their ships were returning empty from Australia, they could stop off in Hollandia, Manokwari and Fakfak. In Hollandia the ships could load cocoa from Genyem and carry it to the Droste company in Haarlem. They could also carry cocoa from Serui. Taco de Vries, the 
son of my school headmaster, managed a cocoa plantation in Ransiki. In Fakfak the residents grew nutmeg. So his plan was for the ships to come in to load up on cocoa in Hollandia, as well as in Ransiki, and nutmeg in Fakfak. The cocoa from Yapen Waropen was brought to Manokwari to be loaded onto the ships because the ships could only anchor in large ports.

Someone from North Yapen said: 'Oh, formerly our cocoa sold; it could be exported abroad and we got money. Why can we not do so now?' I replied: 'Well, Bapak, that is because now the economy is controlled by one person. So we are not free to produce our own goods.' He said: 'Ah, if that is the way it is let's be independent!' I said: 'We can be independent in this respect, if we dare let the centre (Jakarta) know we are capable of managing our own economy. So we must be brave!'

By the end of the 1970s, many areas of Papua were occupied by people from outside of Papua. I remember that in Bintuni Bay, Mbak Tutut (Siti Hardijanti Rukmana, President Soeharto's daughter) was getting company shares amounting to 30 billion rupiah each year. The other day I met her in Jakarta; I tried to persuade her that, given the authority of her father, we could use their money to finance a livestock breeding company in Manokwari and Fakfak.

But she said that her father shook his head to that. Ah, no problem, we could use her money to undertake it. Actually, we wanted to focus the business on Manokwari. Manokwari was all the same as Fakfak, since they were close. Or we could try doing it later in Bintuni Bay. Ah, but Kaimudin, a native of Fakfak and graduate of the Uncen Faculty of Economics, said: 'Oom, there is no market'. I replied: 'The market is no problem, because it is for foreign exports. We can look at the experience we had in the Dutch period, when we imported meat from Venezuela and from Australia. So, how about selling meat abroad?' He said his head ached from thinking about it. Well, however much it might hurt, we still had to make it work.

Ah, I remember the raja of Rumbati, Bapak Ibrahim Bauw. He went to trade wood as far away as Japan. Why could he do it, even though he was already old and in the Dutch period he only had an elementary school education? You university graduates must do better.

Nowadays, ${ }^{3}$ the power of Soeharto is still strong, although it has begun to wane; they still remain wealthy. Recently, with Reverend Herman

3 This interview was held in 1999, a year after Soeharto's retirement. 
Awom we met someone from the Indonesian Air Force (AURI). He said: 'I propose, in the name of the Church, that 70 percent of Soeharto's wealth be handed over to the government, and 30 percent left for him'. But Awom said: 'That can't be, he should only be allowed one percent'. Then I met a colleague of mine at Uncen, a notary, who said: 'Pak, Soeharto made an effort to get that wealth, so it must be fifty-fifty - 50 percent for him and 50 percent for the state'. I proposed 40 percent for Pak Harto and 60 percent for the state. But Amin Rais said: 'No!' Amin Rais is the chairman of the MPR, and he has family relations with Ibu Tien Soeharto. I said: 'Pak Amin, don't think about political succession, instead let's develop the people's economy'. So I asked him to work out an economic concept for Bintuni Bay.

He agreed he would come to Bintuni, but he never showed up. Recently I said to him: 'Pak Amin, be careful! If you promise to go somewhere, but don't turn up, never go there again! Later, once you see there is a lot of mining, only then will you want to go there?' We have the three waves. True, it is a superstition, but it actually happens. When you cross from Bentuni to Babo, the three waves come and hit the boats, then enter the river. The people steering the boats know the waves. So they can withstand the crossing. But if you do not know the situation, you won't get there.

Talking about the power of the Family, this is the difference with the 60s when Soeharto himself had the monopoly of power. Autonomy in 1969 was just a word But now the people of Papua insist on occupying the highest functions in the government of the region.

The Papuans asked to occupy the important positions. But for Fakfak the Indonesians said: 'For security reasons, a Papuan cannot serve as bupati in Fakfak'. In fact, the real reason was their economic interests in Freeport. After A.S. Onim served as bupati, all the bupati in Fakfak came from the army, and this kept up until the beginning of this year, when the position was taken over by Wahidin.

TEACHING AT UNCEN

In 1995 I left the civil service. But in 1994 a friend called me to teach Criminal Law at Uncen because I knew the teaching material. Previously in the 60s we had studied it. At the time, Subagio and Subroto, who 
came from Solo, taught Criminal Law. They read Dutch with a Javanese accent, then went away. Later, I and someone from Sangir translated it into Indonesian for our friends.

There was a former office head who wanted to take his baccalaureate exam; he had great difficulty reading Dutch. So he asked me: 'Pak, how is this pronounced?' He was afraid and shy. 'You should recite a prayer, the $\mathrm{Al}$ Fatihah (first chapter of the Qur'an). After you've read one verse, answer one question. The Dutch terms sound like this: uitvoering, not oeitvoering.' Later you will embarrass yourself if you pronounce it this way.

Finally, he managed to answer all the questions to the end. When he passed, he hugged me and wept. Ah, you always said: 'Hollands spreken, Hollands spreken', but you were not willing to study, and found it hard later on. But the Javanese women were willing to learn, when they came to Dok II. I said to one of them: 'Hey, Tuti, you were a WIK-moeder here in Hollandia before'. A WIK-moeder was a mother who supported the WIK football club in Hollandia. Back then there were the WIK and ZIGO football clubs.

My last job in the field of administration was to serve as a regional assistant to the governor. As government agents we always made visits to the regions. My administrative area covered Nabire, Wamena, Jayapura and Sarmi. At that time I recommended that Sarmi become a separate kabupaten (regency). Above Dabra lay the village of Fawi, which later became a kecamatan (sub-district). Then Fawi was upgraded to the capital of Central Mountains regency, which is now called Ilagah, and has Mulia as the regency capital. I proposed that because I saw Fawi as an excellent area: it was not too hot, not too cold, and located in a plain. Also, the economy, education, animal husbandry, forestry, and fisheries there were all good. The people there could develop themselves. And the Dani people here were very happy that the development of their region would bring them money.

My nephew, who worked as a vaccinator, flew by helicopter to give injections to the people around Dabra as far Mamberamo. According to him, the Mamberamo was not that healthy, so the Dani people were moved to Burmeo. Then I told the people there: You should get hooks and snails, to fish in the rivers, then eat the fish. Seeing the results, they were pleased and wanted to live there permanently. 
My relative worked for the Regional Health Office. I told him that this method would benefit the community. And the people would be willing; this way, they would move from the mountain areas to the coast. It was true that the coastal areas were hot, but because there was a way to make a living there, they were willing. There was a good man from Makassar called Harun. He was married to a woman from Dabra, and he had a rice-growing enterprise. He owned the rice fields, and the people who worked his rice fields were Dani. And every year he supplied the rice needed in the surrounding area.

He came over, and I met with him and said: 'Harun, if there were, let's suppose, ten people like you, we in Jayapura wouldn't need to bother importing rice. Rather, we could use the potential of the existing land to meet our rice needs.' Recently I saw that funds from the World Bank were transferred to farming communities in East Koya. We told them to work the land and plant rice manually. And the results have been satisfactory. Although it is still new, the operation is good and very productive. Compared to the rice harvests in Merauke, those produced in Koya Timur are even better.

The women said to me: 'Pak, let's just sell it for 1,000 or 2,000 rupiah per kilo'. I replied: 'Don’t, ladies. It will sell - don’t worry. People from PNG will also want to buy it.' Incidentally, at the time we had an indigenous association that was headed by my niece's husband. Last December, we created a joint market on the border. People from PNG came as well as people from this side of the border. They brought stuff from here to there, and the PNG people brought their products from there to here. Then we bartered and sold things to each other. 